\title{
Influence of microwave pre-treated Palm Kernel Shell and Mukah Balingian coal on co-gasification
}

\author{
R. Ahmad ${ }^{1 *}$, M. A. M. Ishak ${ }^{2,3}$, K. Ismail ${ }^{1,3}$, N. N. Kasim² \\ ${ }^{1}$ School of Environmental Engineering, Universiti Malaysia \\ Perlis, 02600, Arau, Perlis, Malaysia \\ *Email: razi@unimap.edu.my \\ Phone: +609798626; Fax: +609798636 \\ ${ }^{2}$ Faculty of Applied Sciences, Universiti Teknologi MARA \\ Campus Arau, 02600 Arau, Perlis, Malaysia. \\ ${ }^{3}$ Coal and Biomass Energy Research Group, Universiti Teknologi MARA \\ 40450, Shah Alam, Selangor, Malaysia.
}

\begin{abstract}
In this study, microwave irradiation pretreatment of palm kernel shell (PKS) and Mukah Balingian (MB) coal was carried out in a fixed bed reactor. The effect of microwave power and processing time was investigated on pretreated PKS and MB coal characteristic. Then, the co-gasification of microwave pretreated PKS and MB coal was conducted to examine the effect of product yield and gases composition. The results showed that, the characteristics of pretreated sample was improved with increasing microwave power and processing time. The volatile matter, oxygen content and $\mathrm{O} / \mathrm{C}$ ratio of pretreated sample decreased, while the calorific value, fixed carbon and carbon content of pretreated sample increased with increasing microwave power. The carbon content of pretreated PKS was closed to the untreated MB coal with comparable calorific value was obtained. The microwave power of $450 \mathrm{~W}$ and processing time of 8 min were appropriate to upgrade the PKS and MB coal for co-gasification. The pretreated sample produced higher gas yield and lower tar and char yield than the untreated sample during co-gasification. This result was due to low moisture and oxygenated compound of pretreated feedstock made it appropriate to be converted in cogasification. Moreover, co-gasification of pretreated sample produced the higher $\mathrm{H}_{2}+\mathrm{CO}$ and $\mathrm{CH}_{4}$ and lower $\mathrm{CO}_{2}$ composition than untreated sample. Thus, it can be concluded that the microwave irradiation pretreatment on PKS and MB coal performed the significant impact on the product distribution and composition during the co-gasification.
\end{abstract}

Keywords: Microwave irradiation; torrefaction; pretreatment; Palm Kernel Shell; Mukah Balingian coal; co-gasification.

\section{INTRODUCTION}

In recent years, the increasing emission of $\mathrm{CO}_{2}, \mathrm{SO}_{\mathrm{x}}$ and $\mathrm{NO}_{\mathrm{x}}$ has become a concern on the utilization of the world energy [1, 2]. In the midst of limited availability of fossil fuels and high level of air pollution, energy efficient technologies are gaining importance and 
gasification being highly efficient technology, has received significant attention [3, 4]. Currently, coal is the main feedstock in gasification and is expected to be applied as the energy resource for many decades ahead. However, this direction difficult to achieve due to the increasing in energy demand that had caused the shortage supply and reducing of high rank coal [5]. Consequently, one of the approaches is to utilise the abundant low rank coal and biomass in thermal conversion [6].

High-rank coals, comprising bituminous and anthracite coals, contain high carbon and low moisture content than low rank coals. Low rank coals include brown coal, lignite and sub-bituminous coals have lower energy content due to low carbon content. The low rank coals is almost partial of the world's entire coal deposits compared to the high rank coal [7]. The usage of low rank coals in thermal conversion is economical, due to its low pricing. However, low rank coal as a substitute to the high rank coal, has several limitations i.e. low calorific value and high moisture and oxygen content [7]. These weaknesses can be minimized by pretreatment of low rank coal [8]. Similarly, the utilization of biomass which is a renewable and environmental friendly resource during gasification imposed several problems. Untreated biomass has relatively low energy, high moisture and oxygenated compound, hygroscopic behavior and poor grindability [6-8]. Therefore, the pretreated biomass which has been improved in energy density, hydrophobicity and grindability overcome the weakness of untreated biomass, then driven to be applied in thermochemical conversion [12].

Most biomass torrefaction and preheated coal applied conventional electric heater, while there is an alternative technology designated microwave irradiation (MI). The pretreatment using MI is an effective technique for upgrading the biomass and low rank coal [13]. Unlike electrical heating methods in which heat gradually enters into samples through normal heat transfer mechanisms (convection, conduction, and radiation) [14], MI utilizes electromagnetic energy to generate heat which can penetrate deep into samples, allowing heating to initiate volumetrically [15].

Co-gasification has been investigated by numerous researchers. Krerkkaiwan et al. [16] found the synergistic effect in terms of higher gas yield, lower tar and char yield at 50 $\%$ biomass blending ratio with coal. Howaniec and Smolinski [17] reported that the cogasification increased total gas yield and $\mathrm{H}_{2}$ yield compared to individual gasification. Yuan et al., [18] stated that there was synergistic effects in the decreasing of char yield and increase of gas yield in co-conversion of coal/biomass mixtures. Consequently, the synergistic between biomass and coal co-gasification increases the gas yield, gasification efficiency and reactivity of char whereas reduces the tar yield. Most of the blending in co-gasification utilized untreated biomass and coal.

Dudynski et al. [19] reported that effective and stable gasification with lower tar production was obtained from torrefied pellets in comparison to untreated biomass and suggested that pretreated biomass more appropriate to be applied for co-gasification. Kuo et al. [20] produced higher syngas yield using torrefied bamboo in fixed bed reactor system. Definitely, torrefaction creates the gasification behaviour of biomass approach to that of coal where the $\mathrm{H}_{2}$ composition in syngas of torrefied biomass comparable is with coal. Therefore, the pretreated feedstock which had been improved in their properties enhance the gasification performance and $\mathrm{H}_{2}$ production in syngas [21]. Thus, the co-gasification of pretreated PKS and pretreated MB coal is absolutely innovative in this area. 
The objective of the research was to inspect the microwave pretreatment on PKS and $\mathrm{MB}$ at various microwave power and processing time. In addition, the influence of microwave pretreatment on the properties of pretreated materials were determined. Cogasification of microwave pretreated PKS and MB coal were investigated on product distribution and gases composition.

\section{METHODS AND MATERIALS}

\section{Materials}

MB coal from Sarawak, Malaysia was used as the low rank coal sample in this study. The untreated MB coal sample was pulverized and sieved through progressively finer screen to obtain particle sizes of less than $212 \mu \mathrm{m}$. PKS as a biomass sample was obtained from United Oil Palm Mill Sdn. Bhd., Nibong Tebal, Penang, Malaysia. PKS sample was crushed and sieved through progressively finer screen to obtain particle sizes of less than $212 \mu \mathrm{m}$. The untreated MB coal and PKS samples were dried in an oven at $105{ }^{\circ} \mathrm{C}$ for $24 \mathrm{~h}$ for rendering moisture free and finally stored in an air-tight container until the experiments and analyses were carried out.

\section{Microwave Pretreatment}

The pretreatment was carried out in a domestic microwave with technical specifications of $\sim 240 \mathrm{~V}, 50 \mathrm{~Hz}$ and maximum power of $800 \mathrm{~W}$. The microwave output power of 200, 300, 450 and $600 \mathrm{~W}$ were used in this study. During experiment each sample was put in quartz container on the rotating glass plate and place at the center of microwave. The sample was irradiated for 4, 8 and 12 min at the respective microwave power. The final temperature of the sample during the pretreatment process was measured using infrared thermometer immediately after the pretreatment process. The final weight of pretreated sample was measured once it reached the room temperature. The experiment under all of the studied parameters were performed in triplicate to ensure the measurement value and repeatability of the achieved results.

\section{Sample Analyses}

The proximate analysis which analysed the moisture, volatile matter, ash and fixed carbon content was carried out using a Mettler Toledo thermogravimetric analyser (TGA). The ultimate analysis of the samples was carried using elemental analyser CHNS-O Flash 2000. The Leco AC-350 bomb calorimeter was used to determine the calorific value (CV).

\section{Co-gasification Experiment}

The co-gasification of PKS and MB coal were carried out using fixed bed reactor with an internal diameter of $60 \mathrm{~mm}$ and $300 \mathrm{~mm}$ in height at an ambient pressure. An electric furnace surrounding the reactor was use to heat the reactor. A schematic diagram of the experimental set-up is shown in Figure 1. Approximately $5 \mathrm{~g}$ of sample was weighed and positioned inside the reactor. The reactor was flushed with nitrogen gas for $10 \mathrm{~min}$ before the experiment. Then, the samples were heated to the desired gasification temperature with heating rate of $50^{\circ} \mathrm{C} / \mathrm{min}$. A nitrogen flow rate of $0.5 \mathrm{~L} / \mathrm{min}$ was continued to create an inert atmosphere inside the reactor. After the reactor reached the preferred gasification temperature, the steam 
that was produced from the steam generator was introduced into the reactor, and the nitrogen flow was stopped. The steam gasification of the sample was held for $60 \mathrm{~min}$. The experiment was conducted under optimise condition at gasification temperature of $767^{\circ} \mathrm{C}$, biomass blending ratio of $52 \%$ and steam flow rate of $55 \mathrm{ml} / \mathrm{min}$ from our previous studies [22]

The volatile product which left the reactor from the upper side were condensed in a tar trap. The gas was collected in a gas bag every 15 min from the beginning of steam gasification. The remained solid, which is defined as char was weighted. The tar yield in the tar trap was weighted. The gas yield was calculated by difference based on the total mass balances considering the tar and char yield. The gases composition was analysed using portable gas analyser GA5000. The content of $\mathrm{CH}_{4}, \mathrm{CO}_{2}, \mathrm{O}_{2}$ and balance gas was measured by gas analyser. The balance gas was assumed as $\mathrm{H}_{2}+\mathrm{CO}$ since other gases such as $\mathrm{C}_{2} \mathrm{H}_{4}$, $\mathrm{C}_{2} \mathrm{H}_{6}$ and $\mathrm{C}_{3} \mathrm{H}_{8}$ exist in lower concentrations [23].

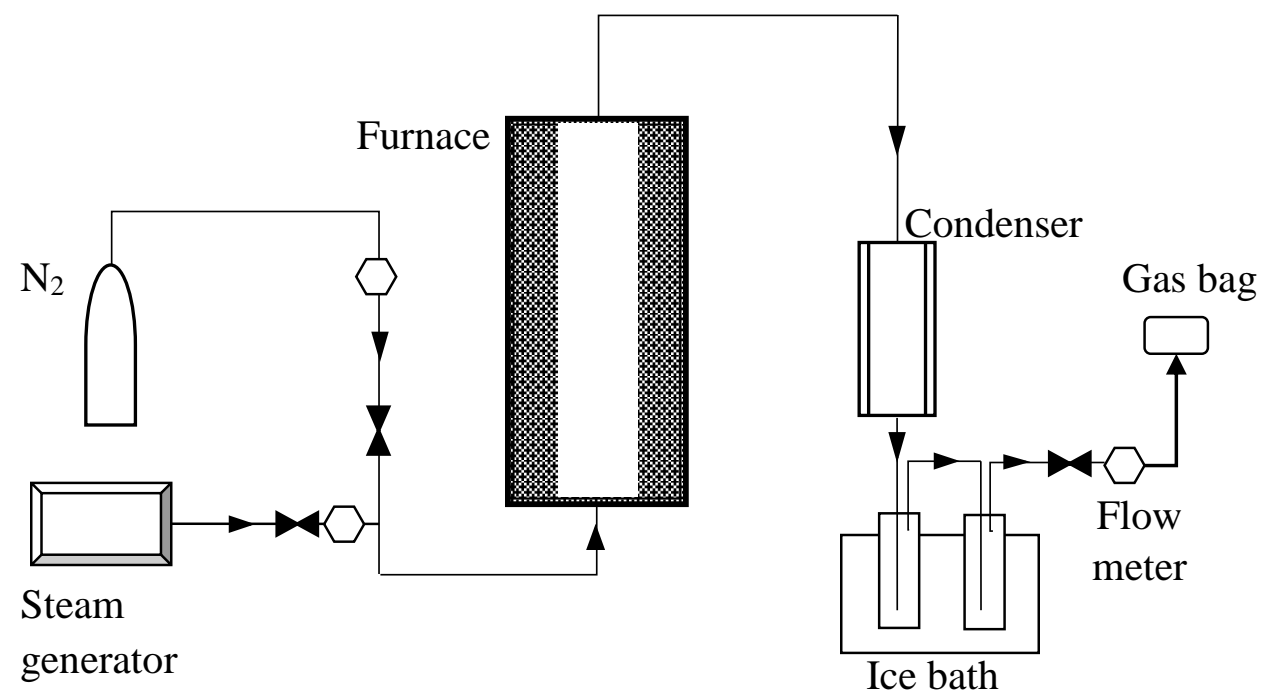

Figure 1. Schematic diagram of fixed bed reactor.

\section{RESULTS AND DISCUSSION}

\section{Temperature Profiles of Pretreated PKS and MB Coal}

Process temperature is one of the most important factors affecting thermal pretreatment. Figure 2(a) and (b) show the temperature profiles of pretreated PKS and MB coal, respectively. It shows that higher microwave power level contributed to high heating rate and final temperature. The pretreated $\mathrm{PKS}$ demonstrate increasing final temperature and heating rate of $50.2^{\circ} \mathrm{C}$ to $470.4^{\circ} \mathrm{C}$ and $12.6^{\circ} \mathrm{C} / \mathrm{min}$ to $117.6^{\circ} \mathrm{C} / \mathrm{min}$, respectively when microwave power level increased from 200 to $600 \mathrm{~W}$ in the first $4 \mathrm{~min}$. These temperature profiles increased much steadily about 4 to $8 \mathrm{~min}$ processing time. Conversely, the temperature increment is not significant at $12 \mathrm{~min}$ processing time regardless the microwave power. Thus, higher processing time of 12 min was not necessary to upgrade the PKS. The microwave power at $600 \mathrm{~W}$ with $4 \mathrm{~min}$, processing time was not suitable for upgrading the PKS, where 
it reached high heating rate of $117.6^{\circ} \mathrm{C} / \mathrm{min}$ as the torrefaction require heating rate equal or below $50^{\circ} \mathrm{C} / \mathrm{min}$ [24].

Figure 2(b) shows the pretreated MB coal temperature as a function of processing time for microwave power of 200, 300, 450 and $600 \mathrm{~W}$. For the sample at 200 and $300 \mathrm{~W}$, the sample temperature increased rapidly during the first $4 \mathrm{~min}$ and then the rate of temperature rise became slower and then began to level off. The sample at 450 and $600 \mathrm{~W}$ behaved in a similar manner but the temperature increased rapidly until 8 min processing with temperature about $110^{\circ} \mathrm{C}$ and subsequently followed by constant temperature stage at around $110^{\circ} \mathrm{C}$ until 12 min processing time. The dewatering process become more intense, rapid, and concentrated at approximately above $100^{\circ} \mathrm{C}$. This temperature remained constant until most of the moisture in coal was removed. The constant temperature stage corresponds to the constant drying rate period in which the free surface moisture is removed. Then, the temperature further increased slowly to remove the remaining moisture, because more energy was required to remove water molecules that were tightly bound. In these experiments, a maximum temperature of about $116^{\circ} \mathrm{C}$ was observed after microwave irradiation for 12 min with $600 \mathrm{~W}$ power. The processing time of $8 \mathrm{~min}$ is adequate to upgrade the MB coal. The temperature variation of pretreated $\mathrm{MB}$ coal during microwave drying showed rather similar trend with Indonesian low-rank coal [25] and Chinese low-rank coal [26].

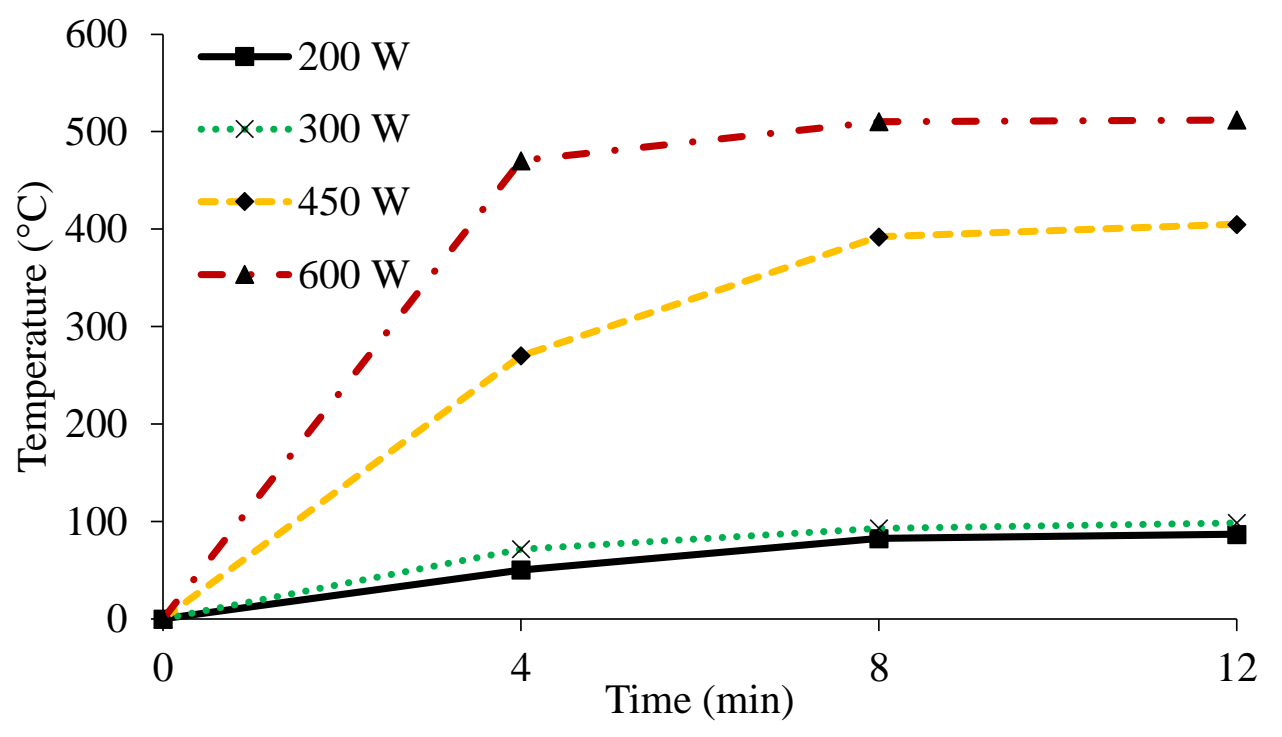

(a) 


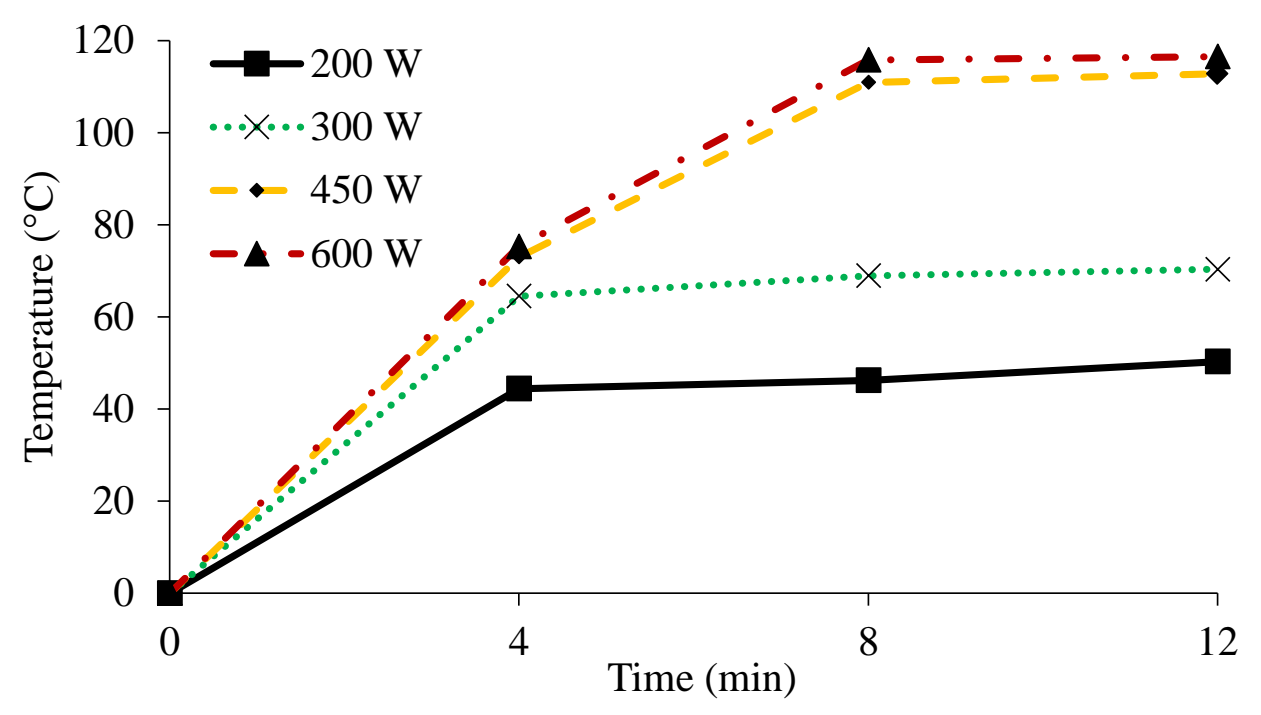

(b)

Figure 2. (a) Temperature profile of pretreated PKS, (b) temperature profile of pretreated MB coal.

\section{Proximate Analysis of Pretreated PKS and MB Coal}

The pretreated PKS and MB coal at 8 min processing time were chosen for proximate analysis based on previous section. Table 1 shows the influence of microwave power on proximate analysis and calorific value for pretreated PKS and MB coal. It can be seen that the moisture content and volatile matter decreased with increasing microwave power. Therefore, the pretreated samples properties were improved due to high moisture content of untreated sample and its capacity in absorbing microwave radiation. The fixed carbon of the pretreated PKS and MB coal increased, with increasing microwave power. The increasing of fixed carbon of the pretreated samples demonstrating an alteration in amount of energy per unit mass which associated to the calorific value. Furthermore, volatile matter decreased with increasing the microwave power due to drying, volatilization, and decomposition of biomass feedstock through the pretreatment of PKS at higher microwave power. While, through the pretreatment of $\mathrm{MB}$ coal, the moisture and volatile matter were released with increased in the coal reactivity [27].

The pretreated PKS had the highest CV of $20.5 \mathrm{MJ} / \mathrm{kg}$ which was $12.6 \%$ higher than untreated PKS at microwave power of $450 \mathrm{~W}$. The pretreated MB coal had the highest CV of $24.7 \mathrm{MJ} / \mathrm{kg}$ which was $22.9 \%$ higher than untreated MB coal at microwave power of $600 \mathrm{~W}$. Generally, higher microwave power level contributed to higher CV of pretreated feedstock. 
Table 1. Influence of microwave power on proximate analysis and calorific value of pretreated PKS and MB coal.

\begin{tabular}{ccccccc}
\hline Sample & $\begin{array}{c}\text { Microwave } \\
\text { power }(\mathbf{W})\end{array}$ & \multicolumn{4}{c}{ Proximate analysis (wt. \%) } & CV \\
\cline { 3 - 6 } & & Moisture & $\begin{array}{c}\text { Volatile } \\
\text { matter }\end{array}$ & $\begin{array}{c}\text { Fixed } \\
\text { carbon }\end{array}$ & Ash & \\
(MJ/kg) \\
\hline Untreated PKS & - & 10.60 & 77.54 & 10.95 & 0.91 & 18.2 \\
PKS & 200 & 6.81 & 62.28 & 29.99 & 0.92 & 17.8 \\
& 300 & 4.25 & 53.04 & 41.63 & 1.08 & 18.8 \\
& 450 & 1.43 & 46.10 & 50.74 & 1.73 & 20.5 \\
Untreated MB & 600 & 3.68 & 24.36 & 69.54 & 2.42 & 20.1 \\
MB & - & 21.50 & 38.00 & 35.60 & 4.90 & 20.1 \\
& 200 & 10.39 & 31.45 & 52.96 & 5.20 & 21.5 \\
& 300 & 8.06 & 29.40 & 57.44 & 5.10 & 22.3 \\
& 450 & 6.81 & 29.02 & 58.87 & 5.30 & 23.6 \\
& 600 & 4.30 & 29.81 & 60.88 & 5.01 & 24.7 \\
\hline
\end{tabular}

Carbon and Oxygen Composition and O/C Ratio of Pretreated PKS and MB Coal Figure $3 \mathrm{a}, \mathrm{b}$, and $\mathrm{c}$ show the influence of microwave power on carbon and oxygen composition of pretreated $\mathrm{PKS}$, pretreated $\mathrm{MB}$ coal and $\mathrm{O} / \mathrm{C}$ ratio, respectively at $8 \mathrm{~min}$ processing time. Generally, the results designate that oxygen decreased while, carbon increased with the increasing microwave power. The oxygen was reduced up to 43 and $33 \%$ for pretreated PKS and MB coal, respectively. Whereas, carbon was increased up to 52 and $62 \%$ for pretreated PKS and MB coal, respectively at the highest microwave power of $600 \mathrm{~W}$. The decreased in oxygen composition, were mostly attributed to the destruction of hydroxyl group (-OH) in PKS and MB coal during pretreatment, which accordingly formed solid hydrophobic fuel. Eventually, by removing oxygen using MI method, the CV and energy density of the pretreated PKS and MB coal increased.

Due to the decomposition and elimination of volatile matter during pretreatment process, the oxygen composition of the pretreated products will be lowered. Therefore, as demonstrated in Figure 3(c), the O/C ratio of all pretreated samples were lower than that of the untreated sample. As the microwave power level increased, the $\mathrm{O} / \mathrm{C}$ ratio of pretreated PKS and MB is gradually reduced as more volatile matter being released as a result of the continuous decomposition process. Moreover, the decrease in $\mathrm{O} / \mathrm{C}$ ratio with the increasing microwave power level from 200 to $600 \mathrm{~W}$ suggests that the coal rank has been upgraded. The reduction of the atomic ratios also indicates the measures of conversion efficiency and oxidation degree of pretreated products [25]. 


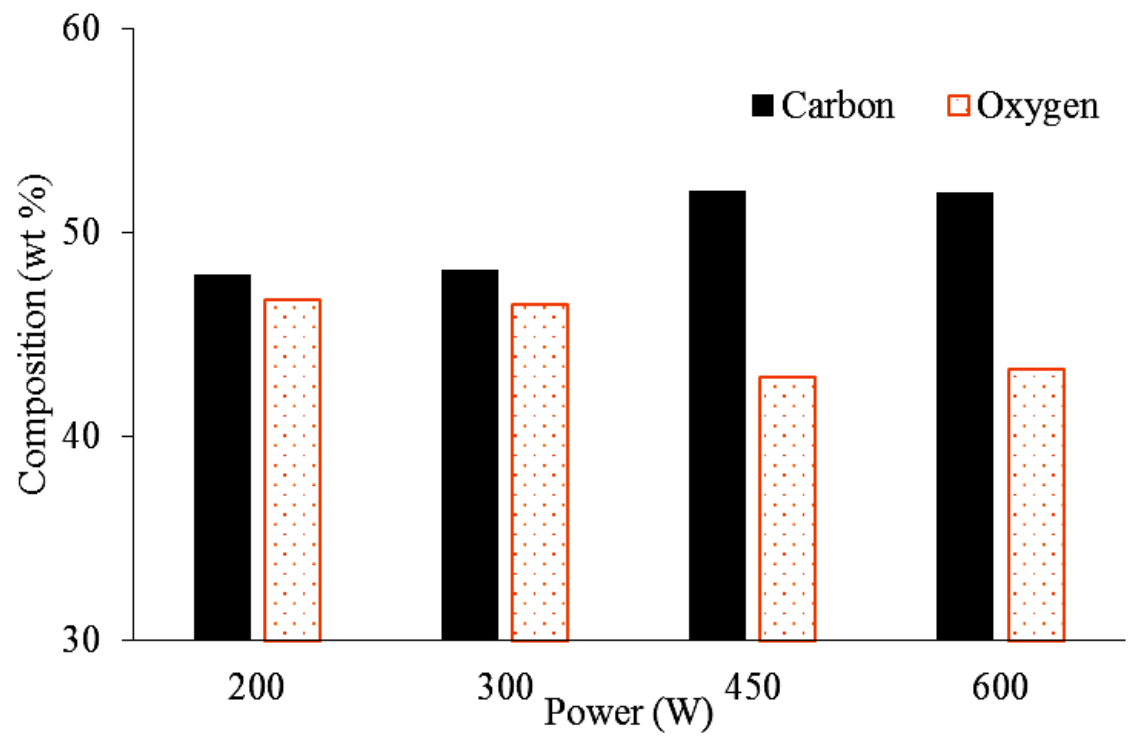

Figure 3(a). Influence of microwave power on carbon and oxygen composition of pretreated PKS.

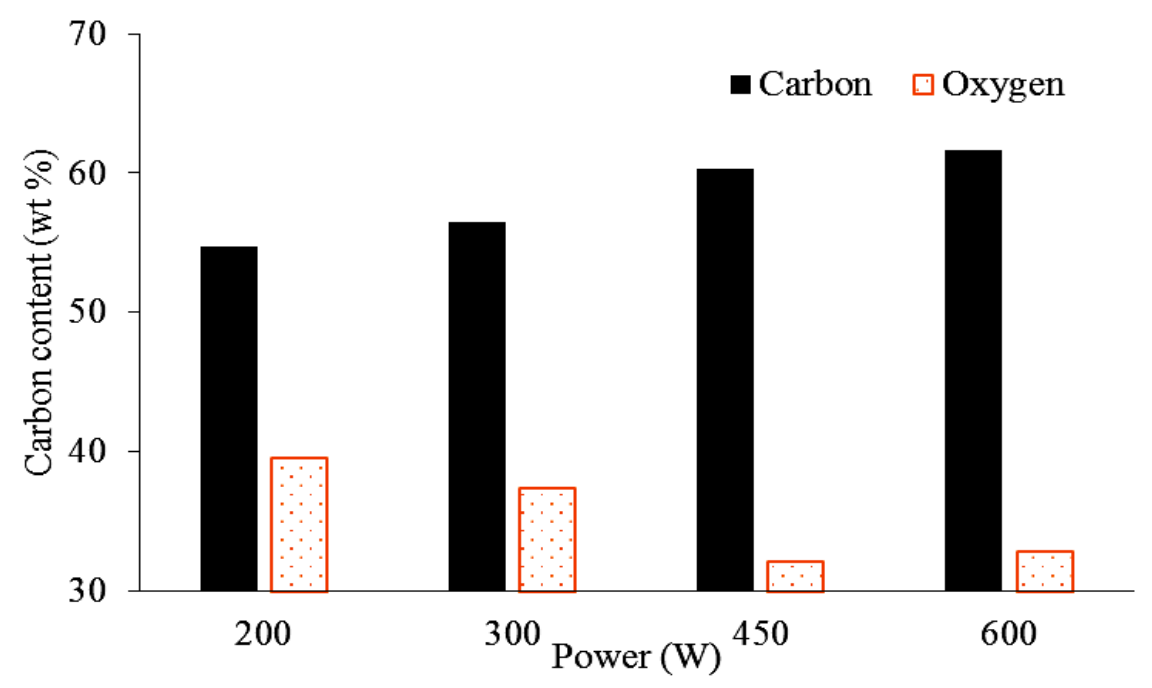

Figure 3(b). Influence of microwave power on carbon and oxygen composition of pretreated MB coal. 


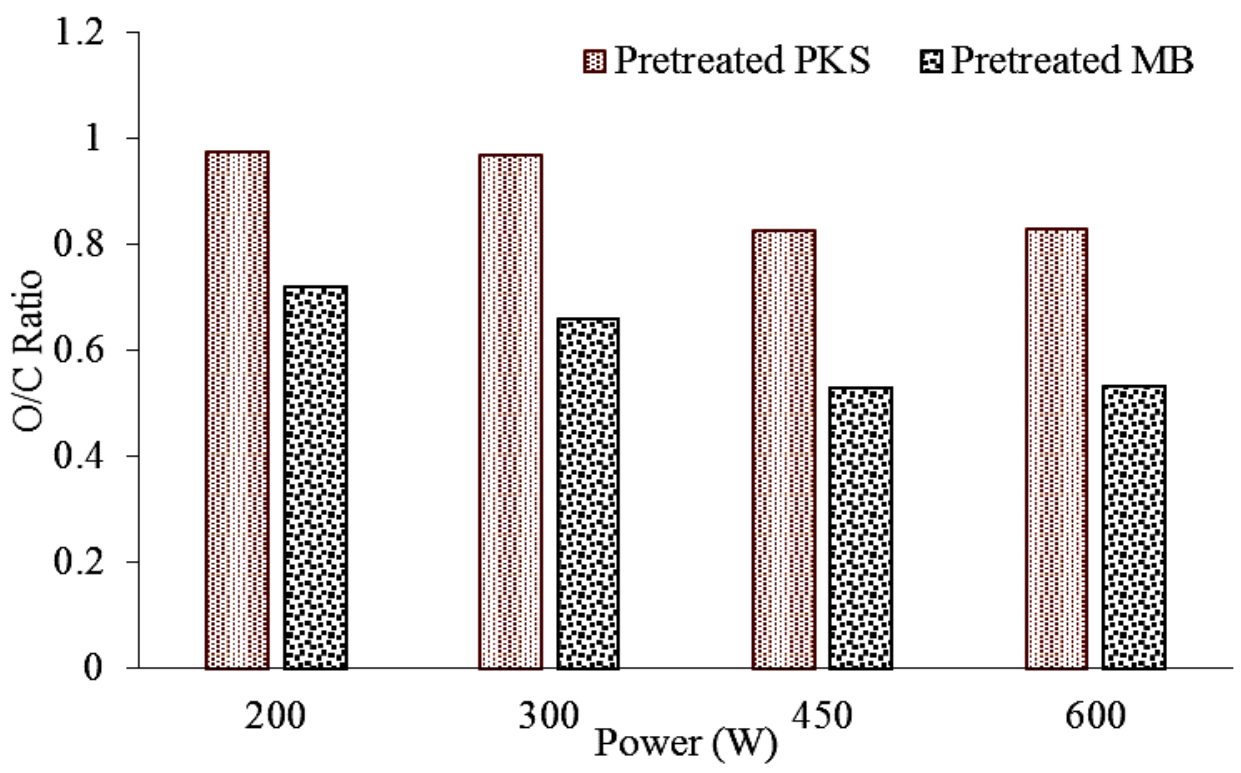

Figure 3(c). Influence of microwave power on O/C ratio of pretreated PKS and MB coal.

\section{Co-gasification of Pretreated PKS and MB Coal}

Figure 4 shows the co-gasification product yield between untreated and preatreated PKS and MB coal. The pretreated samples produced higher gas yield than the untreated sample. The gas yield increased about $20 \%$ using pretreated sample. The pretreated sample exhibited prominent impact on gas production to produce high gas yield compared to untreated sample. The gas production using pretreated sample was higher than Berrueco [26] which increase only $7 \%$ than untreated sample on gasification of pretreated Norwegian forest residue.

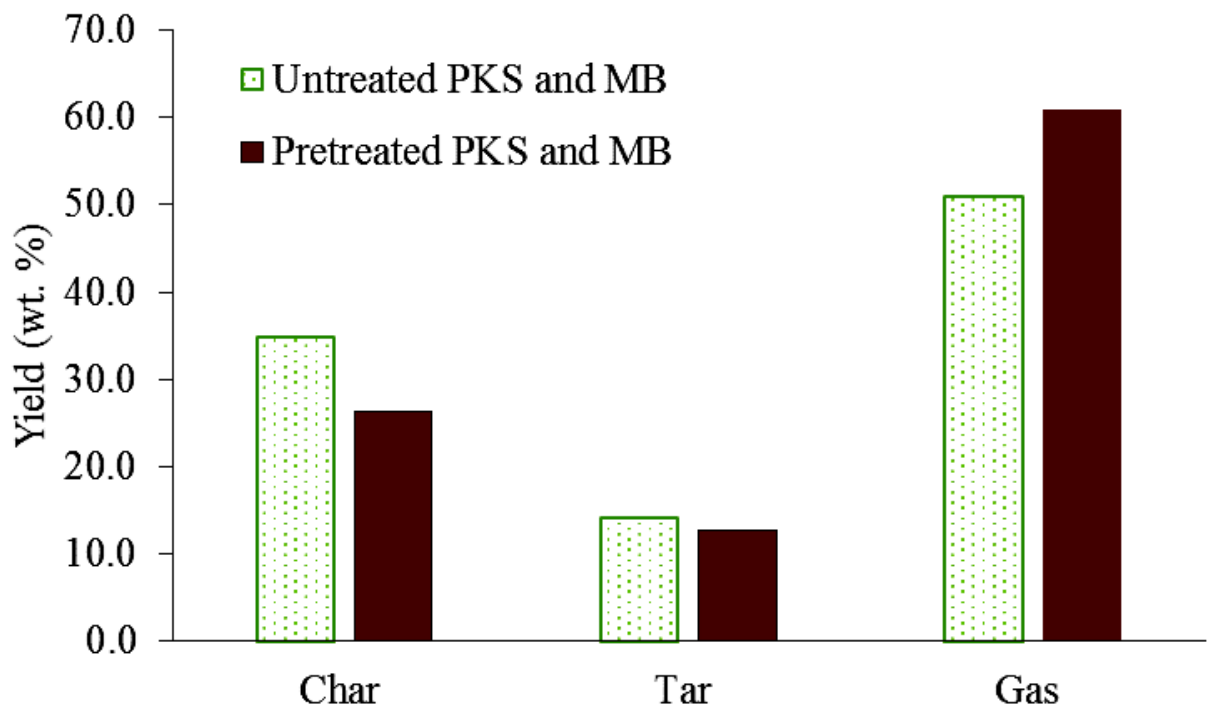

Figure 4. Effect on product yield between co-gasification of untreated and pretreated sample. 
The tar yield reduces from $14.2 \%$ to $12.8 \%$ for pretreated sample. Low tar yield is required in co-gasification. Thus, the pretreated sample reduced the tar yield in co-gasification as an implication of the partial removal of oxygen composition of PKS and MB coal and volatiles through the pretreatment process. The char yield decreased about $30.2 \%$ for pretreated sample. Low char yield for pretreated sample was associated with the increased of conversion to gas product using pretreated feedstock. Moreover, this occurrence was affected from the low moisture and oxygenated compound of pretreated feedstock made it soothing to be converted in co-gasification.

Figure 5 shows the overall gases composition between co-gasification of untreated and pretreated $\mathrm{PKS}$ and $\mathrm{MB}$ coal. The $\mathrm{H}_{2}+\mathrm{CO}$ composition using pretreated sample was higher than untreated sample. The co-gasification of pretreated sample increased the $\mathrm{H}_{2}+\mathrm{CO}$ composition by $19.4 \%$. These indicated that the chemical reaction such as water-gas reaction and steam reforming reaction which favour production of $\mathrm{H}_{2}+\mathrm{CO}$ was greater on cogasification of pretreated feedstock. The $\mathrm{CH}_{4}$ composition showed that the co-gasification of pretreated PKS and MB coal enhanced the $\mathrm{CH}_{4}$ than untreated sample. This proved that the co-gasification of pretreated sample able to convert the heavy hydrocarbon in tar yield to light hydrocarbon gas such as $\mathrm{CH}_{4}$. Co-gasification of pretreated sample exhibited reduction of $\mathrm{CO}_{2}$ composition by $33.8 \%$ as compared to co-gasification of untreated sample.

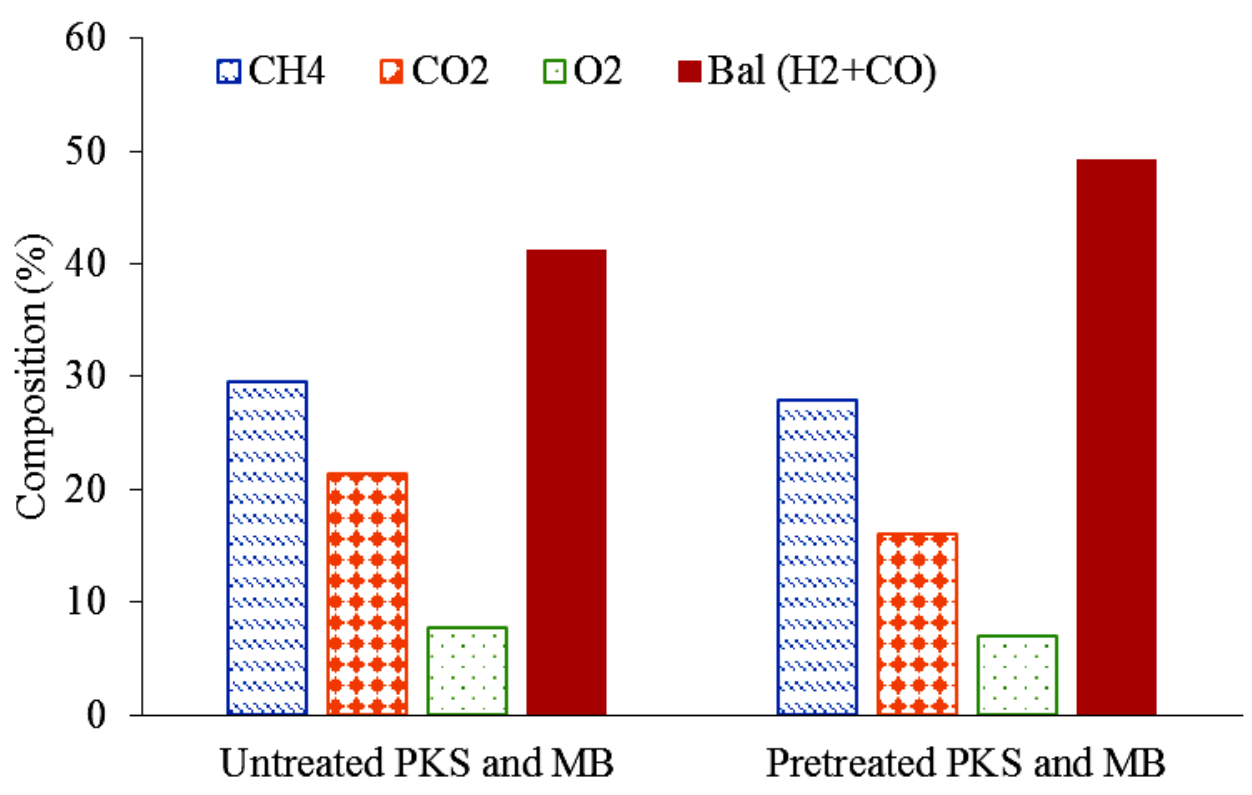

Figure 5. Effect on gases composition between co-gasification of untreated and pretreated sample.

\section{CONCLUSIONS}

The influences of microwave irradiation pretreatment on PKS and MB coal was investigated. It was determined that the $\mathrm{CV}$, fixed carbon and carbon content increased, however, volatile matter and oxygen content reduced, as the microwave power increased. The pretreatment 
showed the optimum parameter at microwave power of $450 \mathrm{~W}$ and processing time of 8 min to produce a good quality fuel. The co-gasification of microwave pretreated PKS and MB coal shows a positive effect in terms of product yield distribution by producing $20 \%$ higher gas yield than co-gasification of untreated sample. The $\mathrm{H}_{2}+\mathrm{CO}$ composition increased by $19.4 \%$ and $\mathrm{CO}_{2}$ composition decreased by $33.8 \%$ through co-gasification of pretreated PKS and MB coal. Consequently, the pretreated PKS and MB coal which had been enriched in their properties improved the gasification performance in term of product yield and gases composition.

\section{ACKNOWLEDGEMENTS}

This research project is funded by the Ministry of Higher Education, Malaysia under Fundamental Research Grant Scheme (FRGS/1/2017/TK10/UITM/02/11). The authors acknowledge Universiti Teknologi MARA and Universiti Malaysia Perlis for providing facilities during the research work.

\section{REFERENCES}

[1] Heidenreich S, Foscolo PU. New concepts in biomass gasification. Progress in Energy and Combustion Science. 2015;46:72-95.

[2] Aniza N, Hassan S, Inayat M. Thermogravimetric kinetic analysis of Malaysian poultry processing waste material under inert and oxidative atmospheres. Journal of Mechanical Engineering and Sciences. 2016;10(2):1943-1955.

[3] Ramos A, Monteiro E, Silva V, Rouboa A. Co-gasification and recent developments on waste-to-energy conversion: A review. Renewable and Sustainable Energy Reviews. 2018;81:380-398.

[4] Inayat M, Sulaiman SA, Kumar A, Guangul FM. Effect of fuel particle size and blending ratio on syngas production and performance of co-gasification. Journal of Mechanical Engineering and Sciences. 2016;10(2):2187-2199.

[5] Mohr SH, Wang J, Ellem G, Ward J, Giurco D. Projection of world fossil fuels by country. Fuel. 2015;141:120-135.

[6] Izzatie NI, Basha MH, Uemura Y, Hashim MSM, Afendi M, Mazlan MAF. Copyrolysis of rubberwood sawdust (RWS) and polypropylene (PP) in a fixed bed pyrolyzer. Journal of Mechanical Engineering and Sciences. 2019;13(1);4636-4647.

[7] Rao Z, Zhao Y, Huang C, Duan C, He J. Recent developments in drying and dewatering for low rank coals. Progress in Energy and Combustion Science. 2015;46:1-11.

[8] Xia W, Xie G, Peng Y. Recent advances in beneficiation for low rank coals. Powder Technology. 2015;277:206-221.

[9] Chen W-H, Peng J, Bi XT. A state-of-the-art review of biomass torrefaction, densification and applications. Renewable and Sustainable Energy Reviews. 2015;44:847-866.

[10] Ahmad R, Hamidin N, Ali UFM, Abidin CZA. Characterization of bio-oil from Palm Kernel Shell Pyrolysis. Journal of Mechanical Engineering and Sciences. 2014;7:1134-1140. 
[11] Abdulrazik A, Mohamad Noor MZ, Failaka MF, Elkamel M, Elkamel A. Utilising biomass for renewable energy production: optimal profitability evaluation from different processing routes. Journal of Mechanical Engineering and Sciences. 2017;11(4):3046-3057.

[12] Nhuchhen D, Basu P, Acharya B. A comprehensive review on biomass torrefaction. International Journal of Renewable Energy and Biofuels. 2014;2014:1-56.

[13] Tahmasebi A, Yu J, Han Y, Li X. A study of chemical structure changes of Chinese lignite during fluidized-bed drying in nitrogen and air. Fuel Processing Technology. 2012;101:85-93.

[14] Pickles CA, Gao F, Kelebek S. Microwave drying of a low-rank sub-bituminous coal. Minerals Engineering. 2014;62:31-42.

[15] Kingman SW, Rowson NA. Microwave treatment of minerals: A review. Minerals Engineering. 1998;11(11):1081-1087.

[16] Krerkkaiwan S, Fushimi C, Tsutsumi A, Kuchonthara P. Synergetic effect during copyrolysis/gasification of biomass and sub-bituminous coal. Fuel Processing Technology. 2013;115:11-18.

[17] Howaniec N, Smoliński A. Steam co-gasification of coal and biomass - Synergy in reactivity of fuel blends chars. International Journal of Hydrogen Energy. 2013;38:16152-16160.

[18] Yuan S, Dai Z, Zhou Z, Chen X, Yu G, Wang F. Bioresource technology rapid copyrolysis of rice straw and a bituminous coal in a high-frequency furnace and gasification of the residual char. Bioresource Technology. 2012;109:188-197.

[19] Dudyński M, van Dyk JC, Kwiatkowski K, Sosnowska M. Biomass gasification: Influence of torrefaction on syngas production and tar formation. Fuel Processing Technology. 2015;131:203-212.

[20] Kuo PC, Wu W, Chen WH. Gasification performances of raw and torrefied biomass in a downdraft fixed bed gasifier using thermodynamic analysis. Fuel. 2014;117:1231-1241.

[21] Chen W, Chen C, Hung C, Shen C, Hsu H. A comparison of gasification phenomena among raw biomass, torrefied biomass and coal in an entrained-flow reactor. Applied Energy. 2013;112:421-430.

[22] Ahmad R, Azlan M, Ishak M, Kasim NN. Optimization of Co-gasification process parameters of pretreated Palm Kernel Shell and pretreated Malaysian low rank coal using response surface methodology. International Conference on Mathematics, Engineering and Industrial Applications (ICoMEIA 2018), 2018.

[23] Berrueco C, Montané D, Matas Güell B, del Alamo G. Effect of temperature and dolomite on tar formation during gasification of torrefied biomass in a pressurized fluidized bed. Energy. 2014;66:849-859.

[24] Huang YF, Chen WR, Chiueh PT, Kuan WH, Lo SL. Microwave torrefaction of rice straw and pennisetum. Bioresource Technology. 2012;123:1-7.

[25] Tahmasebi A, Yu J, Li X, Meesri C. Experimental study on microwave drying of Chinese and Indonesian low-rank coals. Fuel Processing Technology. 2011;92(10):1821-1829.

[26] Ge L, Zhang Y, Wang Z, Zhou J, Cen K. Effects of microwave irradiation treatment on physicochemical characteristics of Chinese low-rank coals. Energy Conversion and Management. 2013;71:84-91. 
[27] Yu J, Tahmasebi A, Han Y, Yin F, Li X. A review on water in low rank coals: The existence, interaction with coal structure and effects on coal utilization. Fuel Processing Technology. 2013;106:9-20.

[28] Chen WH, Peng J, Bi XT. A state-of-the-art review of biomass torrefaction, densification and applications. Renewable and Sustainable Energy Reviews. 2015;44:847-866.

[29] Berrueco C, Recari J, Güell BM, del Alamo G. Pressurized gasification of torrefied woody biomass in a lab scale fluidized bed. Energy. 2014;70:68-78. 